DOI https://doi.org/10.36059/978-966-397-111-7/111-132

\title{
DOMAINS AND STAGES OF CREATIVITY IN CULTURE
}

\section{Tarasiuk L. S.}

\section{INTRODUCTION}

The problem field of creativity and creative work is primarily determined by the fact that the modern crisis society guides the person to the creative personality fulfillment, but at the same time does not provide it with the certain resources for this. At the present stage of the culture development in the age of the global crisis, the establishment of a new worldview paradigm of creativity, required research in the realm of philosophy and cultural studies, is significant. The problem of creativity is always relevant, because new models of life as well as moral values are formed through creativity. Creative personality is significant for culture at all stages of their formation and in a variety of manifestation forms. In connection with this, the necessity to study the phenomenon of creativity appears in the fields of culture, philosophy of culture, philosophical anthropology, which may become a worldview and methodological basis for further research on creativity in other fields of philosophical knowledge.

In a modern "consumption society" (J. Baudrillard) personal creative growth is de-actualized by the focus on material values that generates a person who is a mass consumer. Such person exists at the level of everyday life, which in essence is an impersonal being - das Man (M. Haydegger). In a society of consumption it is very important to understand the importance of creativity and the possibility of its actual, but not illusory implementation in culture. The topicality of the creativity issue is largely caused by the processes of humanization of education in Ukraine, when a creative personality, their abilities and opportunities are getting the supreme value. Therefore, the philosophical study of creativity plays an essential role, which can clarify the dialectic of creativity and a worldview; it will allow distinguishing true creativity from the illusory one. In modern philosophy, creativity is perceived as a way beyond the limits of individual being into collaboration and joint creative work 
(J. Habermas, H. Marcuse). This study presents domains, stages, and forms of creativity, which make it exactly a cultural as well as philosophical and anthropological issue. A person in the modern world understands the meaning of their being as self-fulfillment, self-activity, and self-performance. Each level of the worldview forms its creativity. In order to ensure our social security in the world, it is necessary to be less dependent on circumstances, and to that end one should reveal and implement own creative ideas. Human actions are an indicator of the level of their worldview. The "Western spirit" from the very beginning is selfdisciplined, self-responsible, and value-oriented for functional creativity and self-fulfillment in professional field. The "Eastern spirit" is directed more into the inner world, in the mystery and depth of human nature. "Slavic spirit" is an "anxious spirit" that requires limitation, selfobedience, which, for the sake of public fame, reaches the anarchic uncontrollability of the spirit heroism. In the history of the "Slavic spirit" there was both its humiliation and liberation. Slavery information was laid and transmitted from generation to generation, but the Slavic spirit gave birth to spiritual associates ... The creativity of the Western and Eastern person has always essentially differed, but it is creativity that united people, regardless of nation and origin. Moreover, creativity can unite people with different worldviews, different nations, and different nationalities.

A modern information society lacks for a real, live creative process, capable of filling the human inner world, solving their personal contradictions as well as contradictions in society. During 30 years of the "intellectual revolution" the West was able to gain the social and spiritual powers of people and turn them into productive ones; the preconditions for the transition to the cultural-information level and communicativevalue relations were formed. As a result, there was a reorientation to the social and spiritual productive forces. A creative person, who forms culture, becomes an information capital. It is the creativity that must change technical social production. In a programmable society it is an informational way of self-change. An information flow reveals human consciousness broader and deeper. If the consciousness of a person can perceive this strong, pure flow of information, then through conscious ideas, it is embodied in practical activity. Self-change of a person based 
on their creative powers leads to actualization, fulfillment of thier spiritual potential. However, creativity can overcome the objective world only under the conditions of freedom and love.

Creativity appears to us as a phenomenon of human existence in culture, as a problem of science of culture and philosophical anthropology. It has to overcome obstacles in its path of implementation. There is a problem of actualization of creative abilities of the person, and objectification of creativity. The author introduces a new concept of initiation of creativity, which means the transformation of the creative experience of the person in communication with the Other. The human spiritual growth is the fulfillment through self-cognition and revelation of the depths of consciousness and new creative qualities in a person.

\section{Creativity Domains}

The concepts of "creativity" and "creative work" are close but not identical. Creativity is interpreted as the ability to respond to new conditions, changing them, which also allows you to realize the new in existence, while the process of creating new things may have both conscious and unconscious nature. If creativity is the ability to create a new thing, then creative work is the process of such production; these categories relate to both possibility and reality. On the other hand, they differ in breadth of manifestation in human existence as well: creative work covers mostly the area of arts (rarely - sciences), and creativity - all areas of culture. In order to clarity and understand the concept of "creativity" in more depth, we will try to uncover the domains and stages of creativity revealing in culture. The specificity of creativity as a phenomenon of personality existence in culture is largely determined by the worldview of a person and manifests in different ways, depending on the existential dimension of the worldview (everyday, personal, philosophical) in which a person exists. The significance of creativity, fulfilled in existence of a man and a woman, is in the fact that it creates not only objects of culture, but a subject of culture, a new person. To define such creativity the term of "communicative creativity" is used.

Dimensions of creativity prove its specificity. In the context of philosophical anthropology and philosophy of culture, the specificity of creativity is in spirituality, transcendence, the ability to go beyond own 
boundaries, in warm-heartedness, in nature, in the striving for universality in love. Creativity interacts with the moral values of personalities complementing each other and interacting, which means the emergence of a new integrity of human existence.

We can mention the domains of creativity that allow us to understand the essence of creativity in more depth.

1. A creative person possesses a reserve of physical energy, but they are often calm and contemplative, as if staying in their inner world. They work a lot, demonstrating a high degree of concentration, but distribute aura of freshness, enthusiasm, joy, and inspiration around them. This also points to their innate strength, valuable quality. There are so many examples when people in a very old age radiate strength and health, precisely through creativity. There are also examples of well-known musicians, philosophers, artists who were sick in childhood, but through their creativity they largely overcame their condition, and independently of this, they created the world masterpieces. (Beethoven and his music, he was deaf). Therefore, one can determine the domain of creativity as inspiration, work efficiency, providing for the potential revelation, and even its increase. It seems that people produce the internal energy, moreover, at the expense of their abilities, qualities ${ }^{1}$.

2. Creative people, as a rule, are sagacious and naïve at the same time. As scientists mention, creativity is based on the high intelligence and, at the same time, revealing it. But there are examples which prove both creative work and high intelligence independence. There are studies of Lewis Terman pointing to the correspondence between the intelligence and creative work. Negative correlation of the low intelligence and the level of creative abilities do not have to be explained.

However, rather high level of intelligence may become an obstacle for the creative work. Some owners of high intelligence level differ in arrogance, confidence in their intellectual perfection, but it prevents them from listening to their own intuition.

3. The third domain, paradoxical quality is a combination of wish, discipline, in responsibility. This is the ability to lightness at the same time. A creative person observes events in society, in their life, and very

${ }^{1}$ Чиксентмихайн М. Креативность. Поток и психология открытий и изобретений. М.: Карьера Пресc, 2013, 528 c. 
often, irony of all things seen appears, inspiring for implementation of creative ideas, implementation of own creativity. A person observes the environment, then perceives it sagaciously and generates new ideas, studying them easily ${ }^{2}$.

A creative process has its stages. The fist one is preparation, conscious or unconscious immersion in problem situations, which are of great interest and they awake creative initiative. The second stage of the creative process is a period of thinking over, and it takes time. During this stage the ideas spins at the periphery of consciousness, coming closer and closer to the center of thinking. There unexpected links may appear. Solving the problem consciously, we process information in a linear way. When ideas unite with each other the most unexpected options can appear there. The third stage of the creative process is insight. It is the external clarification when all fragments come to form a whole. In reality some insights can be, when we receive answers, task solutions, options for situations we have experienced. The fourth stage of the creative process is evaluation. A person should decide whether their insight has a value, whether it is necessary to work in this line from now on. As a rule, the part of this stage is the most difficult because a person feels uncertainty and excitement. Here other people's points of view, either support or critics, are significant. Either the idea is really new, urgent, or it is quite obvious. This is a period of self-criticism and own work examination. The fifth stage is improving or making better. The stage requires the largest amount of time, it accounts for the main part of the work. Edison mentioned: "Creative work is one percent of inspiration and 99 percent of perspiration".

There is a danger here: to immerse into improving and do not stop in a good time. Why: because in studies, in insights new and new insights appear every time. That is why it is crucial to stop in a good time and complete the process.

Analyzing and revealing the domains of creativity, it is necessary to mention the stages of revealing the creativity in culture; it will give us the opportunity to understand the essence of creative work and creativity in a global aspect.

2 Чиксентмихайн М. Креативность. Поток и психология открытий и изобретений. М.: Карьера Пресc, 2013, 528 c. 
In the context of a holistic vision, the cultural and philosophical research of creativity appears to us as a human activity in generating life strategies, cultural artifacts, and communication with the Other. Creativity is interpreted as the fundamental factor of human existence in culture; without the presence of creativity, the presence of a person in culture is only virtual and illusory. The ideas of domestic researchers in the fields of philosophy of culture, philosophical anthropology, social philosophy and philosophy of education, who analyzing human existence in culture, focus on the problems of understanding the world in the unity of essentials and existential dimensions. Creativity is determined by the will to selfprotection and procreation of human existence; it is conditioned by the will to power, the will to cognition and creativity, the will to love, freedom and tolerance. In everyday existence, creativity appears as a set of adaptive strategies; manifests itself in the formation of power strategies and culture space. In the spiritual dimension of human existence, creativity is the creation of the existential integrity of love and freedom.

\section{The Stages of Creativity Revealing in Culture}

Such stages as implementation, objectification, actualization and initiation of creativity, make it a problem exactly for cultural studies and philosophical anthropology. It is not enough to have a creative idea, it is necessary to implement it, to realize in the human living space in meaningful forms for society.

The creativity implementation is the process of initial embodiment of the idea in communicating with the Other. On the way of embodiment, the subject of creativity must overcome existential and communicative obstacles, so the implementation of creativity requires a special creativity of conviction. This is the creativity of the outline and the prospect plan.

The objectification of creativity is the process of the idea embodiment in one or another professional material, in an artifact, work (a monograph, a novel, a film, a sculpture, etc.), in something that is more often understood as creativity in the exact meaning of the word. There are an internal creative act and a creative product manifesting externally. It is essential to understand that objectification has an ambivalent nature: either a creative embodiment of the idea or it can be its fall, loss. 
Creative work is a way up, this is a breakthrough to the new world; in the creative condition a person feels enthusiasm; the creative work should overcome substantiality of the world. Thus, the creator faces the world of objectification, and the results of creativity must become a part of culture as an objectification system. This is one of the fundamental problems of creativity that manifests the dramatic nature of creativity. The creativity of the true creator must change the world, and not overload it with new creations. M. Berdyaev rightly notes that in a state of creativity a person is on a certain rise, striving not for the realization of a pragmatic goal, but for the manifestation and embodiment of their inspiration. Thus, a creative person can not keep everything inside; they must go beyond their own limits.

The actualization of creativity is the process of "existential revival" of the work and its author, overcoming the inherent collisions of personality in the creative process. It is actualization of creativity that can prevent from the transformation of work into the object and the product, and the author - into the craftsman. Therefore, the actualization of creativity in some way opposes to objectification: if objectification is the form, then actualization is the meaning. "Actualization, - as V. Frankl mentions, - is a personalization of the world, its spiritualization and creative escape. Actualization as personalization has a hypothetic nature and it is the end of existence. It awakens, constrains and develops freedom and love in existence of a man and a woman"3. Actualization of creativity has its main features: honesty, awareness, freedom and trust. It seems that an actualizing person is "dancing" among their various potentials. Actualization is the transition of creative work from opportunity to reality; it is freedom of creative work and awareness. Creative activity is the result of creative consciousness; it is an attitude to the world, inspired by love for people, respect for human dignity.

Consequently, the transition of ideas into the world, the priesthood of the production of creativity fruits, included in the context of human life, is the actualization of creativity.

The transition of the personality into a creative state is a mystery, dedication, adoration, leading to a peculiar holiness of creativity, a new measure of human responsibility for the creation of their existence and the

\footnotetext{
${ }^{3}$ Тарасюк Л.С. Креативність у вимірах людського буття. Київ: ВД «Освіта», 2017. С. 117-118.
} 
existence of the Other. Therefore, in the research context it is necessary to introduce a new concept - for more adequate and full characteristics of the essence of creativity - "the initiation of creativity" 4 . The initiation of creativity is the process of sacred communication at the interpersonal level, which causes creativity to life. The initiation of creativity takes place in the dialogue between the Master and the Apprentice, which becomes the creativity of the joint creative work dialogue. The initiation of creativity is the beginning of the creative process and, at the same time, its completion. A personality appeals to the initiation of creativity first as the Apprentice, and then conducts it as the Teacher and the Master. The existential dialectics of the initiation of creativity consists in the fact that the true Master becomes the Apprentice with each new apprentice and not only initiates, but also passes through it, updating creative opportunities.

The initiation of creativity appears as a creative transformation of the personality in the context of communication with the Other. Initiation is "dedication", "ritual of transition"; this institute is surprisingly ancient, anthropologists find it in archaic cultures; it exists in every civilization in one form or another. Cult initiations are ceremony of "dedication", "ritual of transition"; this institution is very ancient as well, scientists find its traces in archaic cultures, to a certain extent they exist in modern cultures. The initiation of creativity in the context of the study appears as an opportunity for a person to move from one level of their experience to another through creativity.

The initiation of creativity is in the fact that a particular person reveals abilities and obtains special knowledge, which leads to a greater degree of responsibility for their existence.

Such a person feels the mysterious, sacred power of creativity and creates; it is a sense of sacredness of initiating the transformation of oneself and own existence in culture. It is appropriate to consider the initiation of creativity, in particular, as the possibility of a differentiated transition between male and female principles from one level of their experience to another through joint creative work. In joint creative work, a man and a woman reveal the opportunities of each other, as well as of oneself $^{5}$.

\footnotetext{
${ }^{4}$ Тарасюк Л.С. Креативність у вимірах людського буття. Київ: ВД «Освіта», 2017. С. 118.

${ }^{5}$ Там само. С. 119.
} 
Studying creativity in the context of cultural sciences and philosophical anthropology, there is a need for awareness of the existential uniqueness of fulfillment, objectification, actualization and initiation as stages of creativity revealing. It is not enough to have a creative idea; it must be fulfilled, implemented in life. The process of actualization of personality's potential opportunities is necessary to implement the opportunity into reality. Creativity is always hidden in some mystery; we can only contemplate the product of creativity, and the essence of the inner creative process is partly understood through our own perception of the world. No one yet provided a complete holistic explanation of how creative work appears, how it takes place, because it is always a mystery, the birth of something new. Such concepts as actualization, objectification, implementation, initiation of creativity, make it a problem exactly for cultural studies and philosophical anthropology.

The actualization of creativity comes out as its deep meaning; it is a personalization, spiritualization; therefore, N. Khamitov gives the following explanation on the subject: "Actualization is the term of modern philosophical anthropology, especially existential anthropology and metaanthropology and psychology of personality. It means the orientation of the personality to creative development and interaction with other personalities under the model "I-You". This concept appears in the depths of "humanistic psychology" influenced by the ideas of M. Buber, M. Berdiaev, K. Jaspers and spreads, first of all, in the creative works of E. Shostrom, A. Maslow, C. Rogers. E. Shostrom opposes the personmanipulator, who uses other objects, to the actualizing person-agent, who refers to the other as a unique person. A. Maslow emphasizes the fact that actualization is primarily self-actualization. It is the process of free revealing of person's deep senses and opportunities of own existence. C. Rogers demands to accept any personality as a subject, and not as an object of instrumental influence, in all its completeness and uniqueness of their existential world, which means going beyond the limits of manipulation to actualization and interactive relationship. The concept of actualization acquires the meaning in modern philosophical anthropology and philosophy of culture, which makes it the opposite of the concept of "objectification". Actualization as a focus on interactive relationship with 
the world is the ultimate meaning of any objectification - the monologue - verbalizing action, its otherness. Thus, the process of culture creation can be understood as a fundamental interaction of actualization and objectification. Actualization is a central concept of actualizing psychoanalysis, interpreted as a harmony of spirituality and warmheartedness in communication as well as in the inner world of the personality" ". If objectification is a form, then actualization is meaning. Actualization has meaning only when it comes to the Other, or the personality. The deep meaning of creativity is revealed in the cognition and creation of the Other.

Creativity in its limitless forms is the actualization of the personal principle in the world. Actualization means the growth of the completeness of personality's existence - freedom and love in their combination. On this way, creativity stops being objectification, it transforms into the creation of existence, the existence of creation. Actualization of the personal principle is the ultimate criterion for the depth and truth of the creation existence. It transfers human, objectified creativity to the entire height of the creation existence. Actualization is possible only as a combination of male and female principles. Every loving man, and every loving woman, actualize the Other and at the same time themselves. "Actualization in their existence-making is opposed to objectification, but such antinomy is not antagonism, because actualization can include objectification.

In this case, objectification can only be a moment of existence and creation, actualization is also its sense. Actualization is the personalization of the world, its inspiration and animation. Actualization as personalization has a hypothetical nature and the completion of existence and creation. It awakens, constrains and develops freedom and love in existence of a man and a woman",

In our opinion, the actualization of creativity has the following characteristics: honesty, awareness, freedom, and trust; in this case it is the very action. It seems that an actualizing person is "dancing" among their various potentials. The actualization of creativity is, first of all, its

\footnotetext{
6 Хамитов Н., Тарасюк Л. Креативность. Философская антропология: словарь под. ред. Н. Хамитова. С. 178-183.

${ }^{7}$ Там само.
} 
development - the transition of possibility to reality, this is freedom and awareness; and creativity in its limitless forms is the actualization of the personal principle in the world, which means the growth of the completeness of personal existence - freedom and love in their combination. It can include objectification within itself and, as much as possible, manifests itself at the level of the philosophical worldview. "The most perfect type of worldview is the philosophy that gives the person a diverse, holistic development as a system. A person in their evolution passes through various stages, including the stages of mythological consciousness, religious and philosophical ones. As stated above as for mythological consciousness, it is a certain period, which then changes to a more perfect one. In its essence the religious consciousness does not embody a form of development as well. The experience of all religions shows, that they require, but do not help in solving the problems" ${ }^{\prime 8}$.

Philosophy, namely, philosophical anthropology and cultural studies, must become the confirming and precious researches of the spirit and spirituality.

Philosophers must personally educate themselves for artistic contemplation, encouraging accuracy of their contemplation, master its elements, give flexibility to their perception, striving for completeness. All these imperatives require creativity from the philosopher's side, which requires acting by conscience, forming their spiritual character in such light. The task is not easy, but its achievement is possible: to be - to act to philosophize. A person can think and research only independently, because true thinking is independent; and no scientific study can develop under the plan or through the prohibition. The imposed way of thought kills thinking, and then only verbal visibility remains; that is why a person of thought recognizes the right of others to illusion or mistakes. Every creative work requires freedom - voluntary self-embedding, contemplative initiative, personal inspiration, and love for it. Creativity arises from the inner, unlimited, sacred motivation, which involves individual instinct and which is guided by the personal spirit. Human creative work arises from limitations and suffering, and every creation of culture is overcoming and designing human suffering. For this

8 Хамитов Н., Тарасюк Л. Креативность. Философская антропология: словарь под. ред. Н. Хамитова. С. 178-183. 
overcoming take place, we have to accept our suffering, search for way out, clear and enlighten our hearts. No one can do it instead of us, and outside help can come only in the form of advice, but not in the form of an order or prohibition. There is no creativity without freedom; and someone who does not understand this, never creates anything and does not feel inspired: "A person can experience the act of conscience only freely: open your heart, hear the inner call, accept it and prove it by action. This valuable act can be neither forbidden nor proposed. It is spiritual and holistic, to violate its freedom means to try to leave the person without a conscience, and only conscienceless people can do this". Freedom is an internal factor defining the degree of the human creative program completion.

Essential powers are the reference point of each personal activity and they reveal themselves as actions of spiritual powers. Spiritual tension of the personality creates a special field of interaction between people and internal interaction with themselves, the field as a state of awareness expanding the ability to "spiritual space"; spiritual space as a field of spiritual interaction is the individual space of the personality, in which they interact with themselves and other people in their consciousness. Spiritual space is the very individuality, indivisibility and spiritual substance, which is experienced as a special inner essence. Spiritual space in a person is not much for themselves, as for all, and you can not appropriate "I" for yourself. Recognizing the spiritual essence as only your own, "I" is in illusion. "I-myself" is the alienation of the spirit into possesion, but this is impossible due to the infinite principle of the spiritual, which can not be the property of the finite; this is a manifestation of separating oneself by a spiritual essence. It is impossible to use this spiritual power as an absolute power for self-affirmation on the Earth. This is "spiritual selfishness", in which people, who intend to use the spiritual power for their personal purposes, often fall into.

The revelation of the spiritual essence of a person through creativity has the following manifestations: the space of human communication, mutual understanding on the basis of unified communicative principles, methods; this is a spiritual and communicative power which influence contributes to the emergence of an information society; value-based individualization leading to the historical cultural and value-based unity of 
people and their unification in historical time, in development and improvement. It establishes the value orientations of spiritual unity. "Valuable-based vision" of a person who is spiritually improving themselves, is transferred to all surrounding: "knowledge as a value", "human nature as a value", "animal world as a value", "socio-cultural norms as a value", "a person as a value". The society only helps a person to subjectify their socio-cultural objectivity, to manifest their individuality and individual spiritual essence, and to lay the basic grounds for their selffulfillment, to actualize their abilities.

Creativity is the value-based power that bears the spirit, the true essence of a person. By development of values one can distinguish between temporal changes in the spiritual space of a person. Value-based growth, personal and own potential are the concepts by which you can describe the aspiration of the mature person to sense. It is, as a rule, a process close to self-actualization of a personality or identical to it. The revealing of personal in a person contributes to the actualization of the process of self-development under the certain conditions.

It should be noted that there are features inherent in personal maturity; in this case, creativity is the ability to sensitive perception of disharmony, the creation of something new which has not existed before, a creative orientation. Synergetic nature, autonomy, sociability, selfperception, decentralization, responsibility, tolerance, depth of emotional experience - these are the features that are vivid signs of a selfactualizing personality, inherent in creativity. However, only with a sufficient degree of such features one can talk about personal maturity. A personality who is self-actualizing not necessarily is mature as for personality. At the same time, actualization itself is together with that both a sign and a process of crystallization of the features of personal maturity, a cognitive aspiration for creative existence, that is, to the synthesis of existence and activity, to the creative principle in the essence of a person in real existence-activity in culture.

A person can move from impossibility to possibility confirming their creativity; this movement is a mystery of creativity. We call it the initiation of creativity, namely, the creative transformation of the personality in the context of communication with the Other. Initiation is "dedication", "ritual of transition"; this institute is surprisingly ancient, 
anthropologists find it in archaic cultures; it exists in every civilization in one form or another. Cult initiations are ceremony of "dedication", "ritual of transition"; scientists find its traces in archaic cultures, to a certain extent it exists in modern civilizations. Initiation of creativity in the context of the study appears as the opportunity to move from one level of person's experience to the other level by way of creative work.

To better understand the meaning of the sacred, holiness, one should recall the above definition of the Spirit and the Soul. Under the spirit, we understand the ability to a creative breakthrough and, the breakthrough itself; under the soul - the ability to love and suffer, as well as their existence. It will be correct to determine holiness as the power of the human soul over own spirit and body. Holiness is the power of love and non-violence against evil, which manifests itself in own lives; this is the power of an example and action. To the extent that the qualities of the soul (aspiration for love, tenderness, tolerance) are inherent in the female principle, cleared from its empirical manifestations, to the same extent we can call holiness as the female principle in its highest sense. Holiness as warm-heartedness combines spirit and substance, removing their tragic opposite. We can call initiation of creativity as "holly uncovering". Holiness is in the fact that the particular person is open to knowledge that is closed from the others; and this is the essence of the priesthood, sacredness, and mysteriousness.

The category of the soul is dual, in its existential reality an abyss between the two extremes - pity and love - is revealed, but as femininity it can rise above pity and become love that will unite it with the spirit. It is in that moment that it becomes holiness; holiness is the liberation from the nature of matter, and in this liberation a greatness emerges, which manifests itself in existence, presented in the spiritual and cognitive action, aimed at developing the creative existence of the person themselves in the process of realizing the spiritual and cognitive activity of their spiritual power. But is it possible? For example, modern physics answers that it is possible; firstly, the existence of special elementary particles - virtual particles that can create virtual compositions - is examined, and secondly, tachyon particles that are able to change the time course, and, thirdly, spatial quarks due to gravitational fields. This suggests that some changes may occur with space and time, which can 
evolve physical reality. In conditions of psycho-kinetic phenomena of a person there is their ability to influence material objects; the creation of "internal realities" is a real act - this is an internal virtual reality: greater than "creative reality", the inner spiritual space of knowledge.

Due to the free aspiration for creativity, the will is not subject to social sanctions and is not canceled by the order. In social self-fulfillment one can find freedom, if it corresponds to the world of self-cognition of the spiritual essence of a person; it is superior to all human laws and obeys only the laws of universal existence. Subjective self-fulfillment of the person comes when it is the final goal in itself of the self-improvement object, when a complete self-determination of the spiritual principle is taking place through the individual of the human subject.

Self-fulfillment on the formation of the spiritual essence of the person is significantly different from the vision of everyday and practical ways of self-improvement; it goes beyond the limits of physical definition to the individual area of a person: these are the subtle substances that have to be cognized. The path to spiritual self-fulfillment was laid by a great number of philosophers and thinkers. The spiritual self-fulfillment is not very complex as propaedeutics: self-improvement in a creative activity, individual responsibility for spiritual and value-based determination, selfeducation, self-regulation of own life path, development of individual existence culture as lively culture existence - all this is continuous process of spiritual work - actualization and fulfillment of human creativity.

In the modern world, not paying attention to the complication of social situation, creativity becomes the real transforming power; it is enriched by new philosophical studies, expanding its significance in society essentially, performing spiritual and regulating function in life activity of a person and community. Philosophical anthropology is beginning to develop innovative knowledge, and as a presage of future changes in society, changes for the better, modern anthropology helps to broaden the horizons of thinking, to actualize the philosophical worldview - independent, critical, creative and systemic.

The sense of philosophy is the spiritual rebirth of a person, and this rebirth is the second historical Renaissance for the creative self-fulfillment of each individual human essence. Modern philosophy is the philosophy of the power of the human spirit, which, without imposing the will of 
others, leads to social and spiritual cooperation on the common path of mankind. Modern philosophical maximum is when nobody can win at the expense of another: the individual acts in the measure of self-cognition, the fulfillment of their spiritual essence. In the age of the spiritual revolution, each person must create themselves through the awareness of the creative supreme power that governs all processes; - Creativity; the denial of inner search and the external blind belief are a stagnation of mind and a complete lack of love.

True search is inextricably linked with the creative work and is expressed as a manifestation of the spirit in action, in not revealing, but creating action. If we take into account that the human brain consists of trillion synapses, and the amount of nerve cells that transmit information exceeds ten trillion, then even from physiological data the conclusion is drawn about the possibility of enormous potential. One part of people is in the passive state, while other one - in active, the third one is in the state of passive activity; and it means, that active part of people carries out active work on conquest of evolution: creative principle, mind, supreme principle, feelings, wisdom, wisdom of the future, intelligence of the past - these are the issues of active part of mankind. Based on it, one can distinguish the factor influencing human behavior:

1) The level of spirituality;

2) The level of subconscious aggression;

3) The level of person's sociability;

4) A degree of adaptation in a new environment;

5) The level of freedom from traditions established, way of surrounding environment culture existence;

6) The level of consciousness.

Objectification of creativity is a process of idea embodiment in any professional material, in artifact, creative work (monograph, novel, film, sculpture etc.), in something that is understood as creative work in the precise value of the word.

We should note that creativity has two meanings: an internal creative act and a creative product that manifests itself externally. It is important to understand whether a creative embodiment is objectification, whether it is necessary to distinguish objectification and embodiment. In the first section, we pointed out that objectification has an ambivalent nature: 
objectification can be a creative embodiment of the idea, but may be its decline, loss. Creative work is a breakthrough to the new world; in the creative condition a person feels enthusiasm; the creative work should overcome substantiality of the world. Thus, the creator faces the world of objectification, and the results of creativity must become a part of the culture as an objectification system: this is one of the fundamental problems of creativity that manifests the dramatic nature of creativity. The creativity of the true philosopher must change the world, and not only enrich it with philosophical creations. M. Berdyaev considering this issue noted that in a state of creativity a person is on a certain rise, striving not for the realization of a pragmatic goal, but for the manifestation and embodiment of their state. Thus, a creative person can not keep everything inside; they must go beyond their own boundaries. This way a thinker calls an embodiment. But creativity has no form, there is no substance in the creative work, there is no meaning without form; the creative act is always infinite, and the form of creative act is final. Only the art of embodiment of created things in the world of objectification is the very art that manifests itself every time as a result of the resistance of substance to a creative act. Actually, the art of a person is just the transformation of this force of resistance into the creative power, creative weapons. Then, M. Berdyaev says that the creative light in a person may disappear in the established social forms; "the embodiment of the spirit may become an objectification of the spirit, and then the spirit can not be recognized in the embodiment. Objectification of the spirit is an exhaustion of the spirit". He understands the problem of creativity embodiment of a person in the world quite deeply: "creative work is eschatological, because it is associated with the dissatisfaction of this world based on its reasons. Creativity is the end of this world and is the beginning of a new world". The philosopher-personalist is surprised by the fact that the creativity eschatology has not been considered before; he explains this fact from two perspectives of the creative act:

1) The end of the world, the beginning of a new one;

2) Improvement and consolidation of the world.

${ }_{9}^{9}$ Бердяев Н. Дух и реальность. Философия свободного духа. Я и мир объектов. М.: Республика, 1994. $480 \mathrm{c}$. 
The very creative act of cognition also has an eschatological nature. Cognition is objectified and transformed into a kingdom of law, necessity, and the creative freedom of a person is strengthened and tightened in resistance of this world, in its dissatisfaction with creativity, because creativity is the end and a new beginning. Creative work is noumenal by its nature, but it finds itself in a phenomenal world, the product of creativity belongs to phenomena; it covers the eternal. Cognition and creative work are realized through objectification. Based on the analysis of the rational development of reality it can be seen that cognition exists in two forms: 1) Cognition of something that is already known; 2) Cognition of something that is still unknown ${ }^{10}$.

The will and inspiration is necessary to cognize and create. Finding out what is necessary for the performance of cognition and creativity, we reveal the main differences between cognition and creativity.

Cognition is a process of personal experience, analysis and generalization of the non-existent existence, whereas creativity is the process of personal creation of a new existence - it is not just the increase of existence, but the emergence of something original, unrepeated, unique $^{10}$. Cognition is fulfilled through the objectification of existence, creativity is also an act of objectification - the personality does not create the whole world as a whole and not all existence as a whole, but only some objects, defining the idea of the Creator by their internal meaning and form. Both cognition and creativity are the objectification of human freedom, freedom as an opportunity to become and be anyone. In cognition and creativity there are both freedom and inspiration. The will to inspire will magnify the will to power, freeing it from destructive loneliness. Moreover, the will for inspiration overcomes the will as such, as one directional aspiration. The tragic contradiction of cognition and creativity is largely identical to the contradiction of will and inspiration. If will is aspiration for existence, then inspiration is the very existence. The will for inspiration is revealed in the will to cognition and the will to creativity - in two quite contradictory principles; the overcoming of such a contradiction appears in the understanding of creativity as a process that is traced back in culture, but goes beyond its boundaries. The revival and

\footnotetext{
${ }^{10}$ Бердяев Н. Дух и реальность. Философия свободного духа. Я и мир объектов. М.: Республика, 1994. $480 \mathrm{c}$.
} 
development of consciousness is accompanied by split and alienation. A person must survive criticism of self-consciousness, criticism of mind; and passing through objectification is the fate of the spirit in this world. Objectivity in a positive sense can equip and protect a person. Having a positive role in the fallen world, it can both equip and protect a person. M. Berdyaev studied the concept of the objectification of creativity to the very depths, coming to the conclusion that in the mystery of objectification the mystery of the world is hidden, there is a source of evil and the suffering of world life in it ${ }^{11}$. The problem of objectification has nothing to do with the problem of mental, physical and even everyday relationship of subjective and objective.

This problem is existential, which means the split and constriction of the world, alienation and slave dependence; it is generated by the sinfulness of the existential subject, for which everything is exteriorized and obeys the necessity. Signs of objectification of the emergence of objective relations in the world are manifested in the following factors:

1) Alienation of the subject from the object;

2) Prevalence of unique, personal over common, impersonal and universal;

3) Dominance of the necessity, determination from outside, violation and freedom limitation;

4) Adaptation to the infinity of the world and history, to average person, socialization of a person and their mind, originality, which is eliminated.

This is opposed to communication in sympathy and love, overcoming alienation; personalism, expression of personal-individual character of different existence; the transition to the kingdom of freedom, which is defined internally, the victory over slavery of necessity; the prevalence of quality over quantity; creativity over the adaptation. The phenomenon and nomen are determined by the process of objectification. The struggle against the power of objectification is a spiritual uprising of noumena against phenomena, a spiritual revolution. Nomen is a spirit, a personality; there is freedom, a creative energy that operates in this world.

${ }^{11}$ Бердяев Н. Дух и реальность. Философия свободного духа. Я и мир объектов. М.: Республика, 1994. C. 480 
In view of this, the task of creativity, as Berdyaev notes, is the liberation from the necessity, from the violent power of objectivity in nature and history, the acquisition of spirituality and freedom as the completeness of real existence, always personal on its top, personal, and along with that communitarian. The opposing spirit is not by nature, but by a dependent position, externally bound and tied; this world is my objectification, which generates idols and illusions of consciousness, so I can create another, better world. So, creativity is beyond the limits of objectification, it compensates for what the objective world can not give. Everything is limited to the traditional problem of the relationship between the spirit and substance. The material world has a certain reality, and we are in a very large dependence on it.

The prophets of mankind, its creative geniuses come to this world from the noumenal world, they are the messengers of the Spirit. Although, there is no continuous evolutionary process, but there is interrupted, volatile creative process that must be creative and active. The genius is an untimely person, a person who has not adapted to their time, they challenge the world. However, the genius carries the dynamics of the Spirit, it seems that they foresee the ages, showing the illusion of this world. The eschatology of creativity is precisely in the fact that creativity can not overcome the objectification of this world. One can say that the creative embodiments of a person have a double meaning, they reflect the struggle of two worlds. Creative work dies when it can not be implemented: being one of the urgent problems of our society, it demands from a person the products of creativity, without providing any resources for their realization; in addition, creativity must overcome the big obstacles to its objectification.

B. Pascal noted that "the consciousness of person's insignificance is a sign of their greatness". Perhaps, the person of the spirit is aware of their insignificance in the power of cognition and creation, which prevents them from embodying their creative ideas and, at the same time, helps to overcome obstacles in an objectified world.

\section{CONCLUSIONS}

Studying creativity as cultural and philosophical anthropological problem, we came to the conclusion that it has the following stages of 
revealing: actualization, objectification, implementation and initiation. Actualization of creativity is the process of "existential revival" of art work and its author, overcoming immanent collisions of personality in the creative process, and objectification of creativity is a process of idea embodiment in any professional material, artifact, and creative work. We emphasize that implementation of creativity is the process of initial embodiment of the idea in communication with the Other. On the way of embodiment the subject of creativity must overcome existential and communicative obstacles, so implementation of creativity requires special creativity of conviction. Initiation of creativity is the creative transformation of personality in the context of communication with the Other. At the beginning, initiation of creativity may take place as the Apprentice, and then as the Teacher or the Master.

\section{SUMMARY}

A person is vested with the infinite potential of creativity. Do they become creators and what obstacles do they have on the way? Creativity and creative work: are they identical or different? Domains and stages of creativity, self-fulfillment of personality. Initiation of creativity as a secret of moving from one level of existence to another. Relationship between the Master and the Apprentice. Actualization, objectification, implementation are the important stages for creativity revealing in culture. An effort is made to answer these and other questions in the study given. The author carried out philosophical and cultural analysis of creativity phenomenon, namely, domains and stages of creativity in the dimensions of human existence.

\section{REFERENCES}

1. Чиксентмихайн M. Креативность. Поток и психология открытий и изобретений. М.: Карьера Пресс, 2013. 528 с.

2. Тарасюк Л.С. Креативність у вимірах людського буття. Київ: ВД «Освіта», 2017. С. 117-118.

3. Хамитов Н., Тарасюк Л. Креативность. Философская антропология: словарь под. ред. Н. Хамитова. С. 178-183.

4. Бердяев Н. Дух и реальность. Философия свободного духа. Я и мир объектов. М.: Республика, 1994. 480 с. 
5. Бердяев Н.А. О назначении человека. Опыт парадоксальной этики. М.: АСТ: Астрель: Полиграфиздат, 2010. 478 с.

6. Паскаль Б. Мысли. Афоризмы. Серия «Философия». М.: Издво «АСТ», «Астрель», 2011. 240 с.

7. Философский энциклопедический словарь; гл. ред. Ильичев Л.Ф., Федосеев П.Н., Ковлаев С.М. и др. М.: Энциклопедия, $1993.840 \mathrm{c}$.

\section{Information about the author:} Tarasiuk L. S.

Doctor of Philosophical Sciences, Assistant Professor, Assistant Professor at the Department of Philosophy and History

V. I. Vernadsky Taurida National University, 33, Ivana Kudri str., Kyiv, Ukraine. 